plement Altern. Med. 2017;17(1):178. doi: 10.1186/ s12906-017-1677-4

10. Coca A., Monteagudo E., Doménech M., Camafort M., Sierra C. Can the Treatment of Hypertension in the Middle-Aged Prevent Dementia in the Elderly? High Blood Press Cardiovasc. Prev. 2016;23(2):97-104. doi: $10.1007 / \mathrm{s} 40292-016-0144-5$

11. Jaroch J., Łoboz-Grudzień K., Magda S., Florescu M., Bociaga Z., [at. al.] The Relationship of Carotid Arterial Stiffness and Left Ventricular Concentric Hypertrophy in Hypertension. Adv.Clin. Exp. Med. 2016;25(2):263272. doi: $10.17219 /$ acem $/ 34654$

12. Kulshrestha M. Vidyanand. An analysis of the risk factors and the outcomes of cerebrovascular diseases in northern India.J ClinDiagn Res. 2013;7(1):127-131. doi: $10.7860 / J C D R / 2012 / 4918.2686$

13. Liu J., Liu H., Zhao H., Shang G., Zhou Y. [at al.] Descriptive study of relationship between cardio-ankle vascular index and biomarkers in vascular-related diseases. Clin. Exp.Hypertens. 2017;25:1-5. doi: 10.1080/10641963.2 016.1273946

14. Ricci G., Pirillo I., Tomassoni D., Sirignano A., Grappasonni I. Metabolic syndrome, hypertension, and nervous system injury: Epidemiological correlates. Clin. Exp. Hypertens. 2017;39(1):8-16. doi: 10.1080/10641963. 2016.1210629

15. Rhéaume C., Leblanc M. E., Poirier P. Adiposity assessment: explaining the association between obesity, hy- pertension and stroke. Expert. Rev. Cardiovasc. Ther. 2011:9(12):1557-1564. doi: 10.1586/erc. 11.167

16. Schusse C. M., Peterson A. L., Caplan J. P. Posterior reversible encephalopathy syndrome. Psychosomatics. 2013;54(3):205-11. doi: 10.1016/j.psym.2013.01.014

17. Sutin A. R., Scuteri A., Lakatta E. G., Tarasov K. V., Ferrucci $L$. [et al.] Trait antagonism and the progression of arterial thickening: women with antagonistic traits have similar carotid arterial thickness as men. Hypertension. 2010;56(4):617-622. doi: 10.1161/HYPERTENSIONAHA. 110.155317

18. Tocci G., Cicero A. F., Salvetti M., Musumeci M. B., Ferrucci $A$. [et al.] Attitudes and preferences for the clinical management of hypertension and hypertension-related cerebrovascular disease in the general practice: results of the Italian hypertension and brain survey. Clin. Hypertens. 2017;23:10. doi: 10.1186/s40885-017-0066-0

19. Vohr B. R., Allan W., Katz K. H., Schneider K. C., Ment L. R. Early predictors of hypertension in prematurely born adolescents. Acta Paediatr. 2010;99(12):18121818. doi: $10.1111 / \mathrm{j} .1651-2227.2010 .01926 . x$

20. Wang Y., Xu J., Zhao X., Wang D., Wang C., Liu L. [et al.] Association of hypertension with stroke recurrence depends on ischemic stroke subtype. Stroke. 2013;44(5):1232-1237. doi: 10.1161/STROKEAHA. 111.000302

About authors:

Andreeva Olga Sergeevna, MD, Professor, Head of Department for the improvement of the scientific and methodological foundations of medical and social rehabilitation and technical equipment; tel.:+74999060494; e-mail: os_andreeva@mail.ru

Puzin Mikhail Nikiforovich, MD, professor; Department of Nervous Diseases with a course of neurostomatology and psychosomatics; tel.: +74995045476; e-mail: docpuzin@mail.ru

Kiparisova Elena Sergeevna, MD, professor; tel.: +74995045476; e-mail: medinstmcu@inbox.ru Afanasyev Boris Grigorievich, MD, Professor; tel.: +74995045476; e-mail: medinstmcu@inbox.ru Pryanikov Igor Valentinovich, MD, Professor; tel.: +74995045476; e-mail: medinstmcu@inbox.ru Makkayeva Sakinat Magomedovna, MD, Professor; tel.: +79857744541; e-mail: smakeva@mail.ru Gurieva Irina Vladimirovna, MD, Professor; tel.: +79166203000; e-mail: igurieva@mail.ru Karpov Sergey Mikhailovich, MD, Professor; tel.: +7(8652)728412; e-mail: Karpov25@rumbler.ru

\title{
INVESTIGATION OF CLINICAL AND PSYCHOLOGICAL PECULIARITIES OF PATIENTS AT EARLY STAGES OF HYPERTENSIVE ENCEPHALOPATHY
}

Kiparisova E. S. ${ }^{1}$, Karpov S. M. ${ }^{2}$, Denischuk I. S. ${ }^{1}$, Puzin M. N. ${ }^{1}$, Lepaev Yu. V. ' , Khozhenko E. V. ', Omarov M. A. ' , Khalastov I. N. ${ }^{1}$

${ }^{1}$ The Institute of advanced training FMBA, Moscow, Russian Federation

2 Stavropol State Medical University, Russian Federation

\section{ИССАЕАОВАНИЕ КАИНИКО-ПСИХОАОГИЧЕСКИХ ОСОБЕННОСТЕЙ ПАЦИЕНТОВ НА РАННИХ СТААИЯХ ГИПЕРТОНИЧЕСКОЙ ЭНЦЕФАЛОПАТИИ}

Е. С. Кипарисова ${ }^{1}$, С. М. Карпов ${ }^{2}$, И. С. Аенищук ${ }^{1}$, М. Н. Пузин ${ }^{1}$, Ю. В. Аепаев ${ }^{1}$, Е. В. Хоженко ${ }^{1}$, М. А. Омаров ${ }^{1}$, И. Н. Халястов ${ }^{1}$

\section{${ }^{1}$ Институт повышения квалификации Фелерального меАико-биологического агентства, Москва, Российская ФеАерация \\ ${ }^{2}$ Ставропольский госуАарственный меАицинский университет, Российская ФеАерация}

A complex examination of 97 patients with initial manifestations of hypertensive encephalopathy was carried out. The average age of the examined patients was $46.9 \pm 13.2$ years. The mandatory selection criteria were the presence of hypertension with I or II stage AH, in patients, subjective symptoms of brain damage. The patient's quality of life 
and clinical and psychological characteristics were assessed. For determining the typical features of the psychoemotional sphere, a preliminary study of the intra-group similarity among patients with hypertensive encephalopathy was conducted. It was noted that the correlation coefficients in all cases were at least 0.774 for $p<0.01$, which indicates the presence of intragroup similarity and the existence of a stable psychoemotional of symptom complex in this given nosological group.

Keywords: hypertensive encephalopathy, arterial hypertension, psychoemotional sphere

Проведено комплексное обследование 97 больных с начальными проявлениями гипертонической энцефалопатии (НПГЭ). Средний возраст обследованных пациентов составил 46,9 913,2 года. Обязательными критериями отбора являлись: наличие у пациентов АГ I или II стадии, субъективные симптомы поражения головного мозга. Оценивалось качество жизни больного и клинико-психологические особенности. Для определения типичных особенностей психоэмоциональной сферы проведено предварительное изучение внутригруппового сходства между пациентами с НПГЭ. Отмечено, что коэффициенты корреляции во всех случаях составили не менее 0,774 при p<0,01, что свидетельствует о наличии внутригруппового сходства и о существовании устойчивого психоэмоционального симптомокомплекса в данной нозологической группе.

Ключевые слова: гипертоническая энцефалопатия, артериальная гипертензия, психоэмоциональная сфера

0 ver the past few years great importance is given to the early diagnosis and treatment of arterial hypertension, the prevalence of which according to various sources ranges from 30 to $60 \%$ $[1,9,11,14,16]$. There was an increase in cases of first time diagnosed arterial hypertension among young and middle-aged people. The leading role of arterial hypertension in genesis both chronic forms of cerebral circulatory insufficiency (hypertensive encephalopathy) and acute vascular disorders has been proved, the mortality of which reaches now, according to some data, up to $37 \%[4,7,12,15]$. Along with this, cerebrovascular diseases are the most frequent reasons for seeking medical help [2, $3,5,6,8,10]$. These circumstances determine the medical and social significance of the problem, as well as the urgency of advanced diagnostic reach of pathological changes in the early stages of the disease $[7,9,10,13,14]$.

At the early stage of the hypertensive encephalopathy development there are no clinically significant signs of focal lesion of the central nervous system. As a rule, the cognitive activity of patients remains at a fairly high level $[3,13]$. However, an increase of the assignments volume or a reduction in their implementation time in subjectively difficult situations leads to changes in the psychoemotional state of patients. In these cases, such features as irritability, tearfulness, the emergence of unmotivated fear and anxiety dominate. Often symptoms of asthenia, hypochondriacal or anxiety-depressive disorder, as well as signs of other neurotic manifestations are noted in the form of lack of self-confidence.

Persistent changes in the emotional sphere increased anxiety, waiting for trouble, difficulty in concentration, contribute to high blood pressure, thereby accelerating the development of focal changes in the substance of the brain. Thus long-term emotional disorders are the most salient signs of the transition of the asymptomatic stage of hypertensive encephalopathy to the period of obvious clinical manifestations of cerebrovascular disease. At the same time, an estimation of the psychoemotional sphere of patients with hypertensive encephalopathy is often given insufficient attention.

The purpose of the study was to substantiate the feasibility of the complex state of the psychoemotional sphere of patients with initial manifestations of the hypertensive encephalopathy.

Material and Methods. A complex examination of 97 patients with early manifestations of hypertensive encephalopathy was carried out. The average age of the examined patients was $46.9 \pm 13.2$ years. The mandatory selection criteria were the presence in patients with stage I or II hypertension subjective symptoms of brain damage (headache, dizziness, cerebral asthenia) in the absence of objective signs of the pathology of the central nervous system, focal neurological syndromes.

The criteria for exclusion from this study was the presence of symptomatic hypertension in patients, signs of stenosing of cerebral vessels and main arteries of the head, connective tissue and blood system diseases and the consequences of neuro. Also patients with demyelinating and hereditary diseases of the nervous system, as well as patients with signs of cardiac and/or respiratory insufficiency type 1 and type 2 of diabetes were excluded.

A comprehensive examination of patients with initial manifestations of hypertensive encephalopathy included a clinical neurologic examination, a comprehensive diagnosis of the psychoemotional state of the patients, ultrasound examination of the main arteries of the head and cerebral vessels, computer and magnetic resonance imaging of the brain, and electroencephalography.

Clinical examination consisted of the collection and quantification of complaints in the form of structured intervals, the study of the anamnesis, the study of the neurological status. For each indicator of complaints, patients were asked to rate the severity of the complaint on a four-point system (0-absent, 1-poorly expressed, 2-moderately expressed, and 3-sever expressed). In addition the treating doctor issues an integral evaluation of the severity of the condition for the underlying disease (expert evaluation) - also on a four-point system.

In addition to the interview an experimental psychological examination was carried out including the SMOL questionnaires, the "quality of life»(QoL), the «anxiety level» of Spiel Berger Khanin, the «Bek's Depression Scale. $S \mathrm{SMOL}$ is a Russian-language adapted version of the Mini-Malt test based on MMPI. The examine patient is asked to agree or disagree with the 71-statement presenting in the questionnaire. Based on the answers, an analysis is made on eight clinical and three evaluation scales (L, F, K). Clinical scales allow todistinguish the following features: 1 - hypochondriacal, 2 - depressive, 3 - hysterical, 4 - level of social adaptation, 6 - psychopathic, 7 - psychoasthenic, 8 schizoid, 9 - hypomanic. At the same time the content of the scaled characteristics, as it can be seen from the themselvesnames, corresponds to the traditional clinical characters systematicsthat goes back to Krepelin, Schneider, Gannushkin, etc. The resulting primary 
result is translated into T-scores, on the basis of which a characterological profile is composed.

The Spielberger-Khanin questionnaire allows us to assess separately the levels of reactive and personal anxiety. The level of reactive anxiety reflects a person's reaction to current stressful situations of a different nature and therefore it is a sufficiently variable time indicator. The level of personal anxiety, being closer in content to characterological indicators, assesses the subject is inclination to see a threat to his prosperity in various situations. Quantitatively the level of anxiety 20-34 points was regarded as low, 35-45 points - as average, over 46 points - as high.

The QoL method allows quantitative give estimate of the quality of life of the examined patients by assessing the relationship to real events or probable negative changes (limitations of physical and mental activity, nutrition, psychoemotional stress, demotion and reduction of wage, etc.) in their lives due to disease. In accordance with the obtained results, QoL was considered low for total values below 2 points.

The Beck Depression Scale allows to study the level of depression of a patient on the basis of a quantitative assessment of individual symptoms of depression represented as 21 groups of statements with different response variants. Quantitatively, the value of 10 points and below is regarded as the absence of clinically significant depression, 11-12 points as mild depression, 21-30 points - moderately severe depression, 31 points or more - severe depression.

Results and Discussion. The analysis of complaints made during the primary inspection showed that all patients had complaints of unequal severity. At the same time, according to expert assessment, in 43 (44\%) patients the complaints were weakly expressed, and in 50 patients $(52 \%)$ - as moderate. Only 4 (4\%) patients presented severe complaints. 43 (44\%) patients showed complained of a general malaise of varying degrees, $86(89 \%)$ of headache, and $62(64 \%)$ of dizziness. The sensation of noise in the head worried 54 (56\%) patients, pain in the heart area was marked by $58(60 \%)$ palpitation had $40(41 \%)$ patients. Disturbances in the psychoemotional sphere of the studied patients were presented mainly in complaints of anxiety-depressive nature (yearning, depression of mood appetite, disorder) and cognitive impairments - in the form of complaints of memory loss and attention. In particular, 68 (70\%) patients noted a decrease of mood, 43 (44\%) - appetite disorder, 48 (49\%) - yearning. Among the most common complaints sleep disturbances were noticed in 76 (78 \%) patients, sense of anxiety in 50 (52\%) and memory loss in $65(67 \%)$. At the same time, only 35 (36\%) patients complainedactivelyof the decrease in wit. Thus, the leading complaints during the primary inspection were: headache, dizziness, sensation of noise in the head and agrypnia, as well as sleep disturbance, decreased mood and memory. To determine the typical features of the psychoemotional sphere, a preliminary study of the intra-group similarity between patients with initial manifestations of hypertensive encephalopathy was carried out. Previously the study of intragroup similarity was carried out for definition of features of psychoemotional sphere. Individual patients profile was formed on thebasis of thecomplaints, the anamnestic data (the duration of the disease), and the results of psychological diagnostic questionnaires. This made it possible to clarify that the correlation coefficient in all cases was $0.774(p<0.01)$. Such values allow us to talk about the presence of an intragroup similarity in the studied indicators, in other words - about the existence of a stable psychoemotional symptom complex in the given nosological group. Subjective assessments of patients with their own conditions, as well as the intensity of their complaints with considering of the expert assessment of the treating doctor turned out weakly or moderate expressed. SMOL test profile presented a more stunted clinic at picture that was characterized by psychosomatic al combination of features: paranoia (inclination to super valued formations, «Stuck» affect), hypochondria (pathological fixation on individual symptoms), hysteria (a tendency to somatization of mental suffering), depression. Modal (most common) indicators for the SMOL test which form the profile described above for the surveyed patient's profile are on the scales $\mathrm{L}, \mathrm{F}, \mathrm{K}, \mathrm{VI}, \mathrm{V} 2$, V3, V4, V6, V7, V8, V9 respectively 54, 50, 39, 59, 57, 58, $44,61,44,37,61$ points.

The presented data reflect date enhancement on the scales of the so-called neurotic triad ( 1 - hypochondria, 2 - depression, 3 - hysteria) and on a scale 6 (paranoid reactions) which is typical for psychosomatic diseases. In addition, there is a decline in indicator on scales 4 (social adaptation), 7 (psychological asthenia), 8 (schizoidism). It is worth mentioning separately a slight increase in the scale 9 (hypomania) of the indicators of energy, vivacity, which are not quite clearly correlated with the above results. Probably in combination with the tendency to the poor presentation of complaints this indicator points to the inherent tendency of this nosological group to alexithymia (difficulties with verbal expression of suffering), sometimes reaching the degree of anosognosia (inconsistency between subjective perception by the patient of his condition and its objective state), as well as the propensity to dissimulation (consciously weakening ofcomplaints, up to their concealment). These results are confirmed by data obtained with the help of other standardized psychodiagnostic questionnaires used in this study. Thus clinically significant depression on the Beck scale (more than 10 points) was detected in 72 (74.2 \%) patients. A decrease in the QL questionnaire (on 2 scores or less) was noted in 91 (93.5 \%) examined patients. An increased level of personal anxiety (according to the Spilberg's test - (46 points and above) was detected in $53(54.8 \%)$ patients, and reactive - in $28(29 \%)$.

Summing up, the results it can be affirmed that carried out clinical and experimental-psychological examination revealed a stable psychoemotional symptom complex in patients with initial manifestations of hepatic encephalopathy. Besides this the obtained data confirmed on the feasibility of detailed study of the psychoemotional sphere in this category of patients with a view to clarifying the psychological characteristics of patients in the early stages of the disease. As an illustration is the patient's illness M., 47 years.

During the initial examination he complained about a headache, occasional head noise and dizziness, rapid fatigue, the intensity of which was assessed as either mild or moderate. In addition, he noted frequent changes of mood, sleep disturbance, episodes of general malaise.

Anamnesis. About five years ago the transient increase in blood pressure up to $150 / 90 \mathrm{~mm} \mathrm{Hg}$ was revealed for the first-time, which was accompanied by a headache of a diffuse nature. The recommendations prescribed by the doctor were followed irregularly. Over the past 2 years he began to note the progressive deterioration of the condition in the form of increased frequency and severity of cephalgia and dizziness. During this period, the increase in blood pressure took a persistent character, there was a sharp increase in it due to various psychoemotional loads. In recent months a frequent change of mood (mostly reduced), fatigue, and sleep 
disturbance have joined. Maternal parents also suffered from hypertension and at the time of hospitalization they were alive. He had been working in his profession for 20 years. He was married and hadtwo children. The patientsmoked, alcohol abusehe denied.

Somatic status. General condition is satisfactory. Increased nutrition. Skin and visible mucous is of pale pink cooler. In the lungs, breathing is vesicular, rales are absent, the heart sounds are muffled rhythmically, the accent of the 2 nd tone on the aorta. BP is $170 / 95$, heart rate is 68 beats per minute, the abdomen is palpated soft, painless. The liver is not enlarged. Physiological dimensions are normal.

Neurological status. Consciousness is clear the patient is oriented and adequate. The mood is reduced. There was no pathology from the cranial nerves. Muscular strength in the limbs is sufficient. No tonic disturbances were detected. Proprioceptive reflexes from the upper to the lower extremities are evenly animated, without a clear difference of sides. There are no pathological stop signs. Coordinating tests he performs correctly. From the side of the sensitive sphere no pathology was revealed.

Paraclinical examination. General blood tests, urine biochemical blood test are without pathology. Electrocardiography: rhythm is sinusoidal; HR is 76 beats per minute; the signs of hypertrophy of the left ventricle have been revealed.

Inspection of the fundus. There are signs of hypertensive angiopathy. Magnetic resonance imaging of the brain. There were no signs of focal lesions of the brain substance.

Duplex scanning of the main arteries of the head. Signs of emerging hypertonic macroangiopathy are without local and systemic hemodynamic changes.

\section{References}

1. Baev V. M., Kozlov D. B. Completeness of restoration of cerebral blood flow in patients with hypertensive crisis complicated by hypertensive encephalopathy. Cardiology in Belarus. 2011;5:239-240.

2. Baev V. M., Kozlov D. B. Velocity of glomerular filtration in patients with hypertensive crisis complicated by acute hypertensive encephalopathy. Cardiology in Belarus. 2011;5:243

3. Baev V. M., Kozlov D. B. Cognitive impairment in elderly patients with acute hypertensive encephalopathy. The successes of gerontology. 2012;25(2):329-333.

4. Aftab S., Manzoor J., Talat N., Khan H. S., Subhanie M. [et al.] Allgrove Syndrome: Adrenal Insufficiency with Hypertensive Encephalopathy. J. Coll. Physicians Surg. Pak. 2016;26(9):790-792.

5. Akhmineeva A., Polunina O., Sevostyanova I., Voronina $L$. Features of microvascular reactivity in patients with bronchial asthma combined with arterial hypertension and ischemic heart disease. Medical news of North Caucasus. 2017;12(1):13-17 doi: 10.14300/ mnnc.2017.12004

6. Archer D. F., Pinkerton J. V., Guico-Pabia C. J., Hwang E., Cheng R. F. Study 3353 Investigators. Cardiovascular, cerebrovascular, and hepatic safety of desvenlafaxine for 1 year in women with vasomotor symptoms associated with menopause. Menopause. 2013;20(1):47-56. doi: 10.1097/gme.0b013e3182775fe9

7. Eurelings L. S., Jaccard J., Moll van Charante E. P., Eikelenboom P., Ligthart S. A. [et al.] The mediating role of cardiovascular risk factors in the relationship between symptoms of apathy and incident cardiovascular disease in community-dwelling older individuals. Int. Psychogeriatr. 2016;28(4):669-679. doi: 10.1017/ S1041610215001751

8. Hung $Y, M$. Chang W. P., Wei J. C., Chou P., Wang P. Y. Midlifeankylosing spondylitisincreasestheriskof cardiovascular diseasesin males 5 years later: a national populationbased study. Medicine (Baltimore). 2016;95(18):e3596. doi: 10.1097/MD.0000000000003596
Electroencephalography. Visual analysis revealed diffuse moderately expressed changes in the bioelectrical activity of the cerebral character in the form of disorganization and a decrease in the amplitude of the a-rhythm, the appearance of irregular single slow waves. Focal and epileptiform activity is not revealed.

Psychological examination. SMOL: L-63, F-51, K-40, $\mathrm{I}-65,2-59,3-57,3-57,3-57,4-45,6-61,7-44,8-38$, 9-57 T-points. The level of reactive (according to Spiel Berger) is 56 points, the level of personal anxiety is 54 points. Total QoL is 6 points. Beck depression scale: is 12 points.

Thus, the presence of a persistent increase of the arterial hypertension for several years with the development of the micro- and macroangiopathy (according to the neuro-ophthalmological signs and the results of duplex scanning of the main arteries of the head) accompanied by the development of subjective symptoms, no focal changes in the brain according magnetic resonance imaging were the basis for diagnosis of initial manifestations of hypertensive encephalopathy.

Conclusions. Comparison of the clinical examination data with the results of psychological testing using standardized psychodiagnostic questionnaires, in particular the relationship between the correlation of deterioration with psychoemotional overloads, the presence of an increased level of depression and anxiety allows us to consider these symptoms in the context of the pathogenetic significance in this disease. It confirms the need for an in-depth study of the pyschoemotional state of patients to identify the psychological characteristics of patients in the early stages of diagnosis and as a result an increase in treatment effectiveness, as well as prevention of complications.

9. Halim S. A., Newby L. K., Ohman E. M. Biomarkers in cardiovascular clinical trials: past, present, future. Clin. Chem. 2012;58(1):45-53. doi: 10.1373/ clinchem.2011.165787

10. Kitano T., Nezu T., Mukai T., Uemura J., Wada Y. [et al.] A case of hypertensive encephalopathy with enlarged optic nerve sheath measured by transorbital sonography. J. Stroke Cerebrovasc. Dis. 2017;26(1):e20-e21. doi: 10.1016/j.jstrokecerebrovasdis.2016.10.014

11. Lavigne P. M., Karas R. H. The current state of niacin incardiovascular disease prevention: a systematic review and meta-regression. J. Am. Coll. Cardiol. 2013;61(4):440-446. doi: 10.1016/j.jacc.2012.10.030

12. Lonnebakken M. T., Gerdts E., Boman K., Wachtell K. Dahlof B., Devereux R. B. In-treatment stroke volume predicts cardiovascular risk in hypertension. J. Hypertens. 2011;29(8):1508-1514. doi: 10.1097/ HJH.0b013e32834921fb

13. Paranthaman R., Greenstein A. S., Burns A. S Cruickshank J. K., Heagerty A. M. [et al.] Vascular function in older adults with depressive disorder Biol. Psychiatry. 2010;68(2):133-139. doi: 10.1016/j. biopsych.2010.04.017

14. Sviridova N. K., Yavorsky V. V. The effectiveness of diagnosis and treatment of cerebrovascular disorders in hypertensive encephalopathy in elderly patients by studying the characteristics of cerebral hemodynamics and cerebral perfusion status. Lik Sprava. 2015;(5$6): 41-46$.

15. Soares-Miranda L., Siscovick D. S., Psaty B. M. Longstreth W. T. Jr., Mozaffarian D. Physical activity and risk of coronary heart disease and stroke in older adults: the cardiovascular health study. Circulation. 2016;133(2):147-155. doi: 10.1161/ CIRCULATIONAHA.115.018323

16. Salinas J. J., Abdelbary B., Castellanos S. Rentfro A., Fisher-Hoch S. P. [et al.] Region of birth and cardiovascular disease in Mexican Americans living in the Texas-Mexico border. Hisp. Health. Care Int. 2013;11(1):21-30. doi: 10.1891/1540-4153.11.1.21 


\title{
About authors:
}

Kiparisova Elena Sergeevna, MD, Professor; Department of Nervous Diseases with a course of neurostomatology and psychosomatics; tel.: +74995045476; e-mail: medinstmcu@inbox.ru

Karpov Sergey Mikhailovich, MD, Professor; Department of neurology, neurosurgery, medical genetics; tel.: +79054101523; e-mail: Karpov25@rumbler.ru

Denischuk Ivan Stepanovich, MD, Professor; Department of Nervous Diseases with a course of neurostomatology and psychosomatics; tel.: +74995045476; e-mail: medinstmcu@inbox.ru

Puzin Mikhail Nikiforovich, MD, Professor; tel.: +74995045476; e-mail: docpuzin@mail.ru

Lepaev Yuri Vasilievich, MD, Professor; tel.: +74995045476; e-mail: medinstmcu@inbox.ru

Khozhenko Elena Vladimirovna, MD, Professor; tel.: +74995045476; e-mail: medinstmcu@inbox.ru

Omarov Magomedsaid Abdulaevich, MD, Professor; tel.: +74995045476; e-mail: medinstmcu@inbox.ru

Khalastov Igor Nikolayevich, MD, DMSc, Leading Researcher of the Scientific and Methodological Center of the Federal Security Service; tel.: +79258917766; e-mail: Inh62@mail.ru

(C) Group of authors, 2017

UDC 616.8-085.2/.3

DOI - https://doi.org/10.14300/mnnc.2017.12079

ISSN - 2073-8137

\section{CORRECTION OF SPEECH AND AUTONOMIC DISORDERS AFTER THE ISCHEMIC STROKE}

\author{
Kurushina O. V. ${ }^{1}$, Barulin A. E. ${ }^{1}$, Karpov S. M. ${ }^{2}$ \\ 1 Volgograd State Medical University, Russian Federation \\ 2 Stavropol State Medical University, Russian Federation
}

\section{КОРРЕКЦИЯ РЕЧЕВЫХ И ВЕГЕТАТИВНЫХ РАССТРОЙСТВ ПОСАЕ ИШЕМИЧЕСКОГО ИНСУАЬТА}

\author{
О. В. Курушина ${ }^{1}$, А. Е. Барулин ${ }^{1}$, С. М. Карпов ${ }^{2}$ \\ ${ }^{1}$ ВолгограАский госуАарственный меАицинский университет, Российская ФеАерация \\ ${ }^{2}$ Ставропольский госуАарственный меАицинский университет, Российская ФеАерация
}

Investigation of 106 patients in the early recovery period of an ischemic stroke is conducted. Autonomic nervous system dysfunction, speech problems and the psychoemotional disturbances are revealed. Strong correlation of aphasia and depression was demonstrated. Efficiency of an antioxidant treatment in correction of the revealed problems at the patients with an ischemic stroke is shown.

Keywords: ischemic stroke, autonomic dysfunction, aphasia, dysarthria

Проведено исследование 106 пациентов в раннем восстановительном периоде ишемического инсульта. Выявлены дисфункция вегетативной нервной системы, речевые проблемы и психоэмоциональные нарушения. Была продемонстрирована сильная корреляция афазии и депрессии. Показана эффективность антиоксидантного лечения при коррекции выявленных проблем у пациентов с ишемическим инсультом

Ключевые слова: ишемический инсульт, вегетативная дисфункция, афазия, дизартрия

n Russia more than 650000 people suffer a stroke each year, and approximately two-thirds of these individuals survive and require rehabilitation. The goals of rehabilitation are to help survivors become as independent as possible and to attain the best possible quality of life. Even though rehabilitation does not "cure" the effects of stroke in that it does not reverse brain damage, rehabilitation can substantially help people achieve the best possible long-term outcome $[1,6]$.

The ischemic stroke is an accident, which, at a favorable outcome, leads to cardinal changes in human life and his relatives [12]. There is no patient without these changes in a way of life, mood and behavior. At the same time traditionally in a clinical picture of a stroke the main influence is given to the focal neurologic deficiency bound to a physical disability, first of all to disturbance of motor function. Meanwhile the psychoemotional disorders, speech problems and dysfunctionof autonomic nervous system arising at appreciable number of the poststroke patients, render on household, social and professional adaptation nearly larger effect, than motor deficiency and become an important problem $[8,11]$.

Changes of autonomic regulation in case of acute brain ischemia are including both direct damage of the suprasegmental centers, and the neurometabolic shifts caused by stress factors. The deviations, arising in the regulating parts of the autonomic nervous system precede hemodynamic, metabolic, respiratory disturbances and, thus, can be the most valuable prognostic symptoms of the patient after the stroke [5]. 